Journal of Agricultural Sciences
(Tarim Bilimleri Dergisi)

\title{
Effect of Different Levels of Direct-fed Microbials Plus Exogenous Fibrolytic Enzymes Additives on the Growth Traits of Dairy Calves
}

\author{
Elifnur Hirik ILLHANa (D), Mete YANAR ${ }^{\text {a* }}$ iD

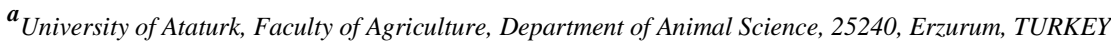 \\ ARTICLE INFO \\ Research Article \\ Corresponding Author: Mete YANAR, E-mail: mtyanar@gmail.com \\ Received: 27 August 2019 / Revised: 07 November 2019 / Accepted: 08 December 2019 / Online: 04 September 2021
}

\section{ABSTRACT}

The study was carried out to investigate to determine effects of the different levels of the direct-fed microbials (DFM) plus exogenous feed enzymes (EFE) on the body weights, weight gains, feed efficiency ratio, some behavioral traits as well as fecal consistency index of male Brown Swiss calves. For this purpose, 18 male Brown Swiss calves were allocated to three groups (control, $10 \mathrm{~g}$ and $20 \mathrm{~g}$ head/day of DFM plus EFE). Weights obtained at weaning time and 6 months of age of the calves in $10 \mathrm{~g}$ head/day of DFM plus EFE group were respectively $7.3 \%$ and $7.1 \%$ heavier than these of animals in control group. The calves in $10 \mathrm{~g}$ head/day of DFM plus EFE group in pre-weaning and between birth and 6 months of age periods also had respectively $16.0 \%$ and $7.3 \%$ higher total weight gains than calves in the control group. Feed efficiency ratio of the calves fed diets with $10 \mathrm{~g}$ DFM plus EFE had
$64.2 \%$ better than that of calves in control group. Average fecal consistency score of the calves fed a diet supplemented with $10 \mathrm{~g}$ head/day of DFM plus EFE had the lowest score $(\mathrm{P}<0.05)$ (i.e., less scouring) compared to other treatment groups in pre-weaning period as well as between birth and 6 months of age. Furthermore, behavioral activities of the calves were not significantly influenced by DFM plus EFE additives except for the percentage of time spent for lying. The study revealed that the feeding of DFM plus EFE to male Brown Swiss calves until 6 months of age had positive but not statistically significant improvement on the growth traits and feed efficiency ratio. On the other hand, it was concluded that the level of $10 \mathrm{~g}$ head/day of the DFM plus EFE additives could be beneficial for reducing incidence of diarrhea in the dairy calves.

Keywords: Calves, Direct-fed microbials, Exogenous fibrolytic enzymes, Brown Swiss, Growth performance, Diarrhea

(C) Ankara University, Faculty of Agriculture

\section{Introduction}

In recent years, the use of antibiotics as a feed additive was banned in the European Union and some other countries including Turkey due to the determination of the adverse effects on human health. Consequently, there has been increased interest in the use of new and safe feed additives such as direct-fed microbials (DFM) and exogenous fibrolytic enzymes (EFE) in ruminant nutrition area (Ran et al. 2019).

Several studies have reported that dairy cattle diets supplemented with DFM changed positively the population of microorganisms in the small intestines, and increased resistance to diseases as well as improved animal health and yield of the ruminants (Ghorbani et al. 2002; Nocek \& Kautz 2006; Weiss et al. 2008; Dutta et al. 2009; Blake \& Clinon 2012; Diler et al. 2015). In addition, some benefits of the DFM can be provided through the prevention of ruminal acidosis (Seo et al. 2010), or by inhibition of food borne pathogens such as E. coli O157:H7 (Wisener et al. 2015).

On the other hand, the effects of DFM on calves have not been revealed in much clarity, and there have been reported different results on this subject (Ulger 2019). In previous studies, Adams et al. (2008), Seo et al. (2010) and Ran et al. (2019) reported that DFM reduces the incidence of diarrhea in calves along with positive effects on weight gain and feed efficiency ratio traits. However, Bakhshi et al. (2006), Frizzo et al. (2008) and Kocyiğit et al. (2015) reported no significant impact of DFM on the growth performance of the dairy calves.

Although addition of EFE into the rations of the non-ruminant farm animals have been widely practiced for a long time, their use for ruminant animals has been remaining quite limited until up to now. On the other hand, besides the increasing feed prices in many countries around the world, the EFE production costs that dropped as a result of biotechnological developments have led to the intensification of studies investigating the possibilities of using EFE in diets of the ruminant animals (Sujani \& Seresinhe 2015). Especially cellulase, hemicellulase, protease and esterase among the fibrolytic enzymes are significant ones because of their potential importance in fiber digestion in ruminants (Ran et al. 2019). Jalilvand et al. (2008), Krueger et al. (2008) and Arriola et al. (2011) reported that EFE supplements added to ration for adult ruminants had positive effects on their 
weight gains and feed efficiency ratio characteristics. On the contrary of the findings of these researchers, Elwakeel et al. (2007), Miller et al. (2008) and Ran et al. (2019) indicated that addition of the EFE additives to the mature bovine diets resulted in no significant difference concerning yield parameters and digestibility traits.

In literature, there is not much information about influences of the EFE on the growth parameters of the pre-ruminant calves (Ran et al. 2019). In one of few studies on the calves, Thakur et al. (2010) indicated that calf starters containing EFE at 1.5 $\mathrm{g} \mathrm{kg}^{-1}$ feed dry matter level resulted in a greater weight gain of calves compared to $3.0 \mathrm{~g} \mathrm{~kg}^{-1}$ feed dry matter level.

DFM plus EFE combination became commercially available recently. However, reports about the effects of feeding mixtures of DFM plus EFE on the growth performance of young cattle are scarce. Therefore, effects of different doses of the DFM plus EFE combinations on weight gains, feed efficiency ratio, fecal consistency score and some behavioral traits of male Brown Swiss calves reared in Eastern Region of Turkey were investigated in this study.

\section{Material and Methods}

The 18 of male brown calves used in the research were obtained from the cattle breeding unit of Atatürk University Food and Animal Husbandry Research and Application Center. At the beginning of the trial, the calves were randomly allocated into three different treatment groups (control, 10 and $20 \mathrm{~g}$ DFM plus EFE). The calves were kept together with their mothers for the first 3 days following birth in order to receive colostrum, and then whole milk was given via calf milk bottle. Total of $4 \mathrm{~kg}$ whole milk was offered to calves in two meals ( $2 \mathrm{~kg}$ in the morning at $7.00 \mathrm{am}$ and $2 \mathrm{~kg}$ in the evening at $5.00 \mathrm{pm})$, and the amount of daily milk was kept constant during the milk feeding period. They were weaned at 56 days of age. DFM plus EFE was given calves by adding to their milk during milk feeding period and then by mixing their calf starters after weaning.

During the trial, two different calf starters in ground form were used. Starter I containing $18 \%$ raw protein was offered to the calves between the seventh day and 4 months of age, while starter II having 17\% raw protein was fed to the calves between 4 and 6 months of ages. Amount of the calf starters was gradually increased from the beginning of the trial, and it was restricted by $2 \mathrm{~kg}$ per calf as suggested by Tuzemen \& Yanar (2004). Dry Hay and water were offered to the calves as ad libitum, and the calves were housed in individual calf pens furnished with hay and concentrate feeders, water bucket as well as calf milk bottle for the duration of the trial. Chemical compositions of the feeds used in this research are presented in Table 1. Amount of feed (whole milk, dry hay and calf starters) consumed daily by each calf was also determined throughout the trial.

Table 1- Chemical compositions of diets used in this study

\begin{tabular}{ccccc}
\hline Composition & Milk & Starter-I & Starter-II & Dry Hay \\
\hline Dry matter (\%) & 12.0 & 88.0 & 88.0 & 87.8 \\
\hline Crude protein (\%) & 3.8 & 18.0 & 17.0 & 7.1 \\
\hline Ether extract (\%) & 4.1 & 4.8 & 4.5 & 3.8 \\
\hline Crude ash (\%) & 0.7 & 8.0 & 10.0 & 8.4 \\
\hline Crude cellulose (\%) & - & 12.0 & 12.0 & 28.4 \\
\hline
\end{tabular}

The combination of DFM plus EFE utilized in this study was purchased from the market in powder form. The feed additives used in research as DFM contained microorganisms such as Lactobacillus casei, Bacillus licheniformis, Lactobacillus plantarum, Lactobacillus acidophilus, Enterococcus faecium, Arpergillus oryzae and Bacillus subtilus while EFE were composed of protease, cellulase, amylase, lipase, and pectinase.

Body weights of the calves were determined at birth, weaning, 4 and 6 months of ages. Body cleanliness scores of the calves during the trial period were evaluated by utilizing Pharmacia calf cleaning and animal health hygiene card used by Panivivat et al. (2004). Fecal consistency scores were determined using a scale whose scores ranged from 1 to 4 and developed by Larson et al. (1977). Bedding cleanliness scores of the straw bedding used on the floor of the calf pens were assessed and recorded according to a scale ranged from 1 to 4 used by Panivivat et al. (2004). In order to evaluate parameters of behaviors of the young animals, proportional calculations were made after determining the behavioral patterns (lying, standing, foraging, water drinking) that occurred at sampling time (once a week) according to the instant sampling method (Martin \& Bateson 1993).

Since it was found out that all parameters investigated in this study had normal distribution, they were statistically analyzed by using the General Linear Model of SPSS statistics program (SPSS 2004). The mathematical model used for analysis of variance was as follows;

$Y_{i j}=\mu+a_{i}+e_{i j}$,

Where;

$\mathrm{Y}=$ Dependent variables

$\mu=$ Overall mean 
$a_{j}=$ Effect of DFM plus EFE doses [j = 1, (control); 2, (10 g/head); 3, (20 g/head)]

$\mathrm{e}_{\mathrm{ij}}=$ Residual error

When F-test for main effect was statistically significant, comparison among levels of DFM plus EFE was carried out by the method of Duncan's Multiple Range Test available in SPSS program (SPSS 2004).

\section{Results and Discussion}

The least squares means for body weights obtained at different ages of the male Brown Swiss calves fed rations containing different levels of DFM plus EFE are presented in Table 2. The differences between DFM plus EFE doses concerning birth weight were found to be statistically insignificant. The absence of a significant difference of birth weights among DFM plus EFE groups could be due to the randomly assignment of the calves to the treatment groups. While the average birth weight of the male Brown Swiss calves was in accordance with results of Yanar et al. (1999), Guler et al. (2006), Tilki et al. (2008) and Soydan \& Sahin (2016), but it was lower than finding of Kaygisiz et al. (2011).

Table 2- Least-squares means along with standard errors and results of variance analysis for weights of male Brown Swiss calves

\begin{tabular}{cccccc}
\hline \multirow{2}{*}{$\begin{array}{c}\text { Parameters } \\
\end{array}$} & $N$ & $\begin{array}{c}\text { Birth Weight } \\
(\mathrm{kg})\end{array}$ & $\begin{array}{c}\text { Weaning Weight } \\
(\mathrm{kg})\end{array}$ & $\begin{array}{c}\text { 4 Months Weight } \\
(\mathrm{kg})\end{array}$ & $\begin{array}{c}\text { 6 Months } \\
\text { Weight }(\mathrm{kg})\end{array}$ \\
\cline { 3 - 6 } & $\bar{X} \pm S_{\bar{x}}$ & $\bar{X} \pm S_{\bar{x}}$ & $\bar{X} \pm S_{\bar{x}}$ & $\bar{X} \pm S$ \\
\hline Overall Mean & 18 & $38.61 \pm 1.57$ & $53.72 \pm 2.27$ & $101.39 \pm 4.05$ & $143.44 \pm 5.17$ \\
\hline Levels of DFM plus EFE & & $\mathrm{NS}$ & $\mathrm{NS}$ & $\mathrm{NS}$ & $\mathrm{NS}$ \\
\hline Control & 6 & $38.17 \pm 2.72$ & $52.33 \pm 3.93$ & $103.83 \pm 7.02$ & $136.50 \pm 8.96$ \\
\hline $10 \mathrm{~g}$ & 6 & $39.50 \pm 2.72$ & $56.17 \pm 3.93$ & $100.33 \pm 7.02$ & $146.17 \pm 8.96$ \\
\hline $20 \mathrm{~g}$ & 6 & $38.17 \pm 2.72$ & $52.67 \pm 3.93$ & $100.00 \pm 7.02$ & $147.67 \pm 8.96$ \\
\hline
\end{tabular}

NS; Non-Significant

As determined in the current study, Kocyigit et al. (2015) also indicated that differences among the weaning weights of female dairy calves fed different amounts of DFM plus EFE were not statistically significant. On the other hand, Timmerman et al. (2005) indicated significantly heavier weaning weight of the calves in DFM group compared to control group. In the present study, weaning weight of the male calves in $10 \mathrm{~g}$ head/day of DFM plus EFE group were $7.3 \%$ heavier than these of animals in control group. Similarly, studies carried out by Jatkauskas \& Vrotniakiene (2010) and Ulger (2019) reported that the weaning weights of the calves in DFM group were $9.4 \%$ and $5.2 \%$ respectively higher than these of calves in control group.

When the least squares means for 4 and 6 month weights were assessed for this study, there was no statistical differences between the control and the 10 or $20 \mathrm{~g}$ head/day DFM plus EFE groups (Table 2). Similarly, Isik et al. (2004) stated insignificant difference between control and DFM groups in terms of 4 months weight, while Ghorbani et al. (2007) determined that the EFE added diets did not significantly affected on the growth performance of Holstein calves at the age of 3 months.

In the current study, 6 months weight of the calves fed diets supplemented with 10 or $20 \mathrm{~g}$ head/day DFM plus EFE were $7.1 \%$ and $8.2 \%$ higher than calves in control group. Similar result was also reported by Kocyigit et al. (2015) who indicated that 6 months weight of crossbred calves in the DFM plus EFE group was 5.7\% greater compared to that of calves in the control group. In another study that supported these results, the 6 months weight of Holstein Friesian calves in the control group was $4.25 \%$ superior to these in control group (Isik et al. 2004).

Least squares means and results of variance analysis for daily weight gains at different stages of the growth of male Brown Swiss calves are presented in Table 3. Although there were no statistically significant differences among the doses of DFM plus EFE, daily weight gains of the calves in $10 \mathrm{~g}$ head/day DFM plus EFE group between birth and weaning period was $16.0 \%$ higher than these in control group. Similarly, during the pre-weaning period, Gorgulu et al. (2003), Dimova et al. (2013), Kocyigit et al. (2015) and Ulger (2019) reported respectively $4.8 \%, 11.8 \%, 20.0 \%$ and $11.9 \%$ higher weight gains of the calves in DFM group compared to control group, and they also indicated that the differences in terms of weight gain at this period were not statistically significant. Furthermore, in a study comparing control group with DFM produced in laboratory conditions or sold commercially, Bayatkouhsar et al. (2013) stated that the weight gain differences among the DFM and control groups at pre-weaning period were $7.9 \%$ and $4.8 \%$ higher in favor of DFM, but the differences were not found to be statistically significant.

In the current study, male Brown Swiss calves receiving $10 \mathrm{~g}$ DFM plus EFE between birth and 6 months of age had superiority of 7.3\% compared to the control group in terms of daily weight gains (Table 3). Similarly, between birth and 6 months of age, Bakhshi et al. (2006) and Kocyigit et al. (2015) reported respectively $4.4 \%$ and $11.7 \%$ higher weight gains of 
the calves in DFM group compared to control group. They also indicated that the differences in terms of weight gain at this period were not statistically significant. However, Higginbothem \& Bath (1993), Abdala et al. (2002) and Hossaini et al. (2010) stated statistically significant differences between calves in DFM and control groups concerning weight gains from birth to 6 months of age period. The differences among the results of the researches could be attributed to different type of viable cells in the DFM additives and their survivability, metabolic capacity and consistency in the host gut. Additionally, different calf rearing systems as well as Influence of feed processing (e.g., steam conditioning, pelleting) on the survivability of the DFM in the final prepared diet might also play significant roles on the inconsistent findings obtained in these studies.

Table 3- Least-squares means along with standard errors for weight gains in different parts of the growth of male Brown Swiss calves

\begin{tabular}{|c|c|c|c|c|c|}
\hline Parameters & & $\begin{array}{l}\text { Gains Between } \\
\text { Birth and } \\
\text { Weaning }(k g)\end{array}$ & $\begin{array}{c}\text { Gains Between } \\
\text { Weaning and } 4 \\
\text { Months of Age } \\
\quad(\mathrm{kg})\end{array}$ & $\begin{array}{c}\text { Gains Between } 4 \\
\text { and } 6 \text { Months of } \\
\text { Age }(\mathrm{kg})\end{array}$ & $\begin{array}{c}\text { Gains Between } \\
\text { Birth and } 6 \\
\text { Months of Age } \\
(\mathrm{kg})\end{array}$ \\
\hline & $N$ & $\bar{X} \pm S_{\bar{x}}$ & $\bar{X} \pm S_{\bar{x}}$ & $\bar{X} \pm S_{\bar{x}}$ & $\bar{X} \pm S_{\bar{x}}$ \\
\hline Overall Mean & 18 & $0.27 \pm 0.02$ & $0.74 \pm 0.03$ & $0.70 \pm 0.05$ & $0.58 \pm 0.02$ \\
\hline $\begin{array}{c}\text { Levels of DFM } \\
\text { plus EFE }\end{array}$ & & NS & NS & NS & NS \\
\hline Control & 6 & $0.25 \pm 0.04$ & $0.80 \pm 0.06$ & $0.54 \pm 0.09$ & $0.55 \pm 0.04$ \\
\hline $10 \mathrm{~g}$ & 6 & $0.29 \pm 0.04$ & $0.69 \pm 0.06$ & $0.76 \pm 0.09$ & $0.59 \pm 0.04$ \\
\hline $20 \mathrm{~g}$ & 6 & $0.26 \pm 0.04$ & $0.74 \pm 0.06$ & $0.79 \pm 0.09$ & $0.61 \pm 0.04$ \\
\hline
\end{tabular}

NS; Non-Significant

Least squares means and results of the variance analysis for amount of dry matter intake of milk, hay and calf starters per $\mathrm{kg}$ weight gain is presented in Table 4. Although the amount of dry matter of the feed per kg weight gain of the calves in the 10 or $20 \mathrm{~g}$ head/day DFM plus EFE groups was not significantly different from control group in the pre-weaning period, the feed efficiency ratio of the calves fed diets with $10 \mathrm{~g}$ DFM plus EFE had 64.2\% better than that of calves in control group. Kocyigit et al. (2015) also stated that feed efficiency ratio of the female dairy calves in $10 \mathrm{~g}$ head/day DFM plus EFE group was 1.7 times better than that of calves in control group. Parallel findings were also reported by Jenny et al. (1991), Hamza et al. (1996), Gorgulu et al. (2003), Is1k et al. (2004) and Ulger (2019), and they indicated respectively 25.1\%, 25.5\%, 15.2\%, $11.1 \%, 10.5 \%$ better feed efficiency ratios of the calves in DFM group compared to control group.

Table 4- Least-squares means along with their standard errors for feed efficiency ratios of male Brown Swiss calves at different stages of the growth

\begin{tabular}{|c|c|c|c|c|c|}
\hline \multirow{3}{*}{ Parameters } & \multirow[b]{3}{*}{$N$} & \multicolumn{4}{|c|}{ Total Amount of Dry Matter Consumed per kg Weight Gain Between; } \\
\hline & & Birth and Weaning & $\begin{array}{l}\text { Weaning and } 4 \\
\text { Months of Age }\end{array}$ & $\begin{array}{c}4 \text { and } 6 \text { Months of } \\
\text { Age }\end{array}$ & $\begin{array}{c}\text { Birth and } 6 \\
\text { Months of Age }\end{array}$ \\
\hline & & $\bar{X} \pm S_{\bar{x}}$ & $\bar{X} \pm S_{\bar{x}}$ & $\bar{X} \pm S_{\bar{x}}$ & $\bar{X} \pm S_{\bar{x}}$ \\
\hline Overall Mean & 18 & $2.31 \pm 0.36$ & $3.25 \pm 0.12$ & $5.19 \pm 0.38$ & $3.51 \pm 0.08$ \\
\hline $\begin{array}{c}\text { Levels of DFM } \\
\text { plus EFE }\end{array}$ & & NS & NS & NS & NS \\
\hline Control & 6 & $2.94 \pm 0.63$ & $3.22 \pm 0.22$ & $4.77 \pm 0.66$ & $3.52 \pm 0.15$ \\
\hline $10 \mathrm{~g}$ & 6 & $1.79 \pm 0.63$ & $3.41 \pm 0.22$ & $4.58 \pm 0.66$ & $3.42 \pm 0.15$ \\
\hline $20 \mathrm{~g}$ & 6 & $2.21 \pm 0.63$ & $3.14 \pm 0.22$ & $6.21 \pm 0.66$ & $3.61 \pm 0.15$ \\
\hline
\end{tabular}

NS; Non-Significant

As the feed efficiency ratios of the male calves in different DFM plus EFE levels during from birth to 6 months of age were compared to each other, it was $2.9 \%$ better in favor of the calves in $10 \mathrm{~g}$ head/day DFM plus EFE group. Similarly, Bakhshi et al. (2006) reported statistically insignificant differences in terms of feed efficiency ratios between DFM and control groups, and they found out that calves in DFM group had 7.7\% better feed efficiency ratio compared to control group. Moreover, Ran et al. (2019) stated that Charolaise x Angus calves consumed diet supplemented with DFM plus EFE had 9.6\% better feed efficiency ratio than calves in control group in a period between birth and 112 days. On the other hand, Timmerman et al. (2005) and Frizzo et al. (2011) especially indicated positive improving effect of the DFM on the feed efficiency ratio of the stressful calves when they had high incidence of disease.

Least squares means and results of variance for the percentage of time spent on different activities of the male Brown Swiss calves are presented in Table 5. While the effect of the different levels of the DFM plus EFE on the percentage of time spent for lying throughout the trial (6 months) was highly significant $(\mathrm{P}<0.01)$, the rest of the behavioral traits were not significantly influenced from the treatment groups. However, the percentage of time spent for eating for calves in $10 \mathrm{~g}$ head/day DFM plus 
EFE group had $10.3 \%$ higher compared to control group. Kocyigit et al. (2015) also reported insignificant differences in terms of percentage of time spent for standing, eating and water drinking behaviors between DFM and control groups.

Table 5- Least squares means with standard error for percentage of time spent on different activities of male Brown Swiss calves

\begin{tabular}{|c|c|c|c|c|c|}
\hline \multirow{3}{*}{ Parameters } & \multirow[b]{3}{*}{$N$} & \multicolumn{4}{|c|}{ Between Birth and 6 Months of Age } \\
\hline & & Lying & Standing & Feeding & Water Drinking \\
\hline & & $\bar{X} \pm S_{\bar{x}}$ & $\overline{\bar{X}} \pm S_{\bar{x}}$ & $\overline{\bar{X}} \pm S_{\bar{x}}$ & $\overline{\bar{X}} \pm S_{\bar{x}}$ \\
\hline Overall Mean & 18 & $0.26 \pm 0.009$ & $0.31 \pm 0.009$ & $0.40 \pm 0.01$ & $0.014 \pm 0.02$ \\
\hline Levels of DFM plus EFE & & $* *$ & NS & NS & NS \\
\hline Control & 6 & $0.29 \pm 0.01^{\mathrm{b}}$ & $0.29 \pm 0.01$ & $0.39 \pm 0.02$ & $0.015 \pm 0.03$ \\
\hline $10 \mathrm{~g}$ & 6 & $0.22 \pm 0.01^{\mathrm{a}}$ & $0.33 \pm 0.01$ & $0.43 \pm 0.02$ & $0.013 \pm 0.02$ \\
\hline $20 \mathrm{~g}$ & 6 & $0.26 \pm 0.01^{\mathrm{ab}}$ & $0.32 \pm 0.01$ & $0.39 \pm 0.02$ & $0.012 \pm 0.03$ \\
\hline
\end{tabular}

**; P<0.01, NS; Non-Significant

Least square means and results of variance analysis for fecal consistency scores, body cleanliness scores along with bedding cleanliness scores of the male Brown Swiss calves in different groups of DFM plus EFE are presented in Table 6. Statistically significant $(\mathrm{P}<0.05)$ differences among the levels of DFM plus EFE concerning fecal consistency scores were observed in the pre-weaning period as well as between birth and 6 months of age. During these periods, calves in $10 \mathrm{~g}$ head/day DFM plus EFE group had $83.4 \%$ and $38.6 \%$ lower fecal consistency scores which meant they had lower incidence of diarrhea. As a result of the decrease in the incidence of diarrhea in these calves, body cleanliness scores $(4.1 \%$ and $8.9 \%)$ and bedding cleanliness scores (16.4\% and 9.0\%) improved compared to control group in the both milk feeding period as well as throughout the trial (Table 6). Similarly, Agarwal et al. (2002), Seo et al. (2010), Kim et al. (2011), Kocyigit et al. (2015) determined the fecal consistency scores of the dairy calves and reported a significant reduction of incidence and duration of scouring in the young animals of DFM fed groups as compared to control group. Additionally, Foster et al. (2003), Jatkauskas \& Vrotniakiene (2010) have shown that supplementation of DFM into the diet of the calves caused a reduction of the incidence of diarrhea in the dairy calves.

Table 6- Least square means and standard error for fecal consistency scores of calves, body cleanliness scores, and bedding cleanliness scores

\begin{tabular}{|c|c|c|c|c|c|c|c|}
\hline Parameters & & $\begin{array}{l}\text { Fecal } \\
\text { Consistency } \\
\text { Scores Between } \\
\text { Birth and } \\
\text { Weaning }\end{array}$ & $\begin{array}{c}\text { Fecal } \\
\text { Consistency } \\
\text { Scores } \\
\text { Between Birth } \\
\text { and 6 Months } \\
\text { of Age }\end{array}$ & $\begin{array}{l}\text { Body Cleanliness } \\
\text { Score Between } \\
\text { Birth and } \\
\text { Weaning }\end{array}$ & $\begin{array}{c}\text { Body } \\
\text { Cleanliness } \\
\text { Score Between } \\
\text { Birth and } 6 \\
\text { Months of Age }\end{array}$ & $\begin{array}{l}\text { Bedding Cleanliness } \\
\text { Score Between Birth } \\
\text { and Weaning }\end{array}$ & $\begin{array}{c}\text { Bedding } \\
\text { Cleanliness } \\
\text { Score Between } \\
\text { Birth and } 6 \\
\text { Months of Age }\end{array}$ \\
\hline & $N$ & $X \pm S_{\bar{x}}$ & $X \pm S_{\bar{x}}$ & $X \pm S_{\bar{x}}$ & $X \pm S_{\bar{x}}$ & $X \pm S_{\bar{x}}$ & $X \pm S_{\bar{x}}$ \\
\hline Overall Mean & 18 & $1.64 \pm 0.06$ & $1.20 \pm 0.01$ & $1.90 \pm 0.07$ & $2.17 \pm 0.04$ & $1.94 \pm 0.06$ & $2.37 \pm 0.06$ \\
\hline $\begin{array}{c}\text { Levels of } \\
\text { DFM plus } \\
\text { EFE } \\
\end{array}$ & & $*$ & $*$ & NS & NS & NS & NS \\
\hline Control & 6 & $2.33 \pm 0.11^{\mathrm{b}}$ & $1.47 \pm 0.02^{\mathrm{b}}$ & $2.00 \pm 0.12$ & $2.32 \pm 0.08$ & $2.13 \pm 0.10$ & $2.55 \pm 0.11$ \\
\hline $10 \mathrm{~g}$ & 6 & $1.27 \pm 0.11^{\mathrm{a}}$ & $1.06 \pm 0.02^{\mathrm{a}}$ & $1.92 \pm 0.12$ & $2.13 \pm 0.08$ & $1.83 \pm 0.10$ & $2.34 \pm 0.11$ \\
\hline $20 \mathrm{~g}$ & 6 & $1.33 \pm 0.11^{\mathrm{a}}$ & $1.08 \pm 0.02^{\mathrm{a}}$ & $1.78 \pm 0.12$ & $2.06 \pm 0.08$ & $1.86 \pm 0.10$ & $2.21 \pm 0.11$ \\
\hline
\end{tabular}

*; P<0.05, NS; Non-Significant

\section{Conclusions}

Overall results of the study revealed that even though the feeding of DFM plus EFE improved numerically weight gain as well as feed efficiency ratio of the male Brown Swiss calves, the differences were not statistically significant. However, level of 10 $\mathrm{g}$ head/day of the DFM plus EFE additives could be beneficial for reducing incidence of diarrhea of male Brown Swiss calves.

\section{References}

Abdala A A, Zimmerman G, Calvinho L F, Gianre V R \& Voltero D (2002). Efficacy of probiotic added to whole milk and to milk substitute. Revista de Medicina Veterinaria 83: 196-198

Adams M C, Luo J, Rayward D, King S, Gibson R \& Moghaddam G H (2008). Selection of a novel direct-fed microbial to enhance weight gain in intensively reared calves. Animal Feed Science and Technology 145(1-4): 41-52 https://doi.org/10.1016/j.anifeedsci.2007.05.035 
Agarwal N, Kamara D N, Chaudhary L C, Agarwal I, Sahoo A \& Pathak N N (2002). Microbial status and rumen enzyme profile of crossbred calves fed on different microbial feed additives. Letters in Applied Microbiology 34: 329-336 https://doi.org/10.1046/j.1472765x.2002.01092.x

Arriola K G, Kim S C, Staples C R \& Adesogan A T (2011). Effect of fibrolytic enzyme application to low- and high-concentrate diets on the performance of lactating dairy cattle. Journal of Dairy Science 94(2): 832-841. https://doi.org/10.3168/jds.2010-3424

Bakhshi N, Ghorbani G R, Rahmani H R \& Samie A (2006). Effect of probiotic and milk feeding frequency on performance of dairy Holstein calves. International Journal of Dairy Science 1(2): 113-119. https://doi.org/10.3923/ijds.2006.113.119

Bayatkouhsar J, Tahmasebi A M, Naserian A A, Mokarram R R \& Valizadeh R (2013). Effects of supplementation of lactic acid bacteria on growth performance, blood metabolites and fecal coliform and lactobacilli of young dairy calves. Animal Feed Science and Technology 186(1-2): 1-11 https://doi.org/10.1016/j.anifeedsci.2013.04.015

Blake K W \& Clinon R K (2012). Direct-fed Microbials and Prebiotics for Animals. Science and Mechanisms of Action. Callaway, TR and Ricke SC (editors). Springer Science Business Media, New York, USA. 148 p.

Diler A, Koçyiğit R, Yanar M \& Aydın R (2015). Effect of feeding direct-fed microbials plus exogenous feed enzymes on milk yield and milk composition of Holstein Friesian cows. Veterinarija Ir Zootechnika 65: 11-16

Dimova N, Baltadjieva M, Karabashev V, Laleva S, Popova Y, Slavov P, Krastanov J \& Kalaydjiev G (2013). Effect of supplementation of Probiotic Zoovit in diets of calves of milk breed. Bulgarian Journal of Agricultural Science Supplement 19(1): 94-97

Dutta T K, Kundu S S \& Kumar M (2009). Potential of direct-fed microbials on lactation performance in ruminants - A critical review. Livestock Research for Rural Development, 21: Article no: 160. http://www.lrrd.org/lrrd21/10/dutt21160.htm. (Erişim tarihi: 5 Ocak, 2016)

Elwakeel E A, Titgemeyer E C, Johnson B J, Armendariz C K \& Shirley J E (2007). Fibrolytic enzymes to increase the nutritive value of dairy feedstuffs. Journal of Dairy Science 90(11): 5226-5236 https://doi.org/10.1079/9780851994642.0221

Foster J C, Glass M D, Courtney P D \& Ward L A (2003). Effect of Lactobacillus and Bifidobacterium on Cryptosporidium parvum oocyt viability. Food Microbiology 20: 351-357 https://doi.org/10.1016/s0740-0020(02)00120-x

Frizzo L S, Bertozzi E, Soto L P, Zbrun M V, Sequeria G, Dalla Santina R, Rodriguez Armesto R \& Rosmini M R (2008). The effect of supplementation with three lactic acid bacteria from bovine origin on growth performance and health status of young calves. Journal of Animal and Veterinary Advances 7(4): 400-408

Frizzo, L S, Zbrun M V, Soto L P \& Signorini M L (2011). Effects of probiotics on growth performance in young calves: A meta-analysis of randomized controlled trials. Animal Feed Science and Technology 169(3-4): 147-156 https://doi.org/10.1016/j.anifeedsci.2011.06.009

Ghorbani G R, Morgavi D P, Beauchemin K A \& Leedle A Z (2002). Effects of bacterial direct-fed microbials on ruminal fermentation, blood variables and microbial populations of feedlot cattle. Journal of Animal Science 80(7): 1977-1985 https://doi.org/10.2527/2002.8071977x

Ghorbani G R, Jafari A, Samie A H \& Nikkhah A (2007). Effects of applying exogenous, non-starch polysaccharides to pre-weaning starter concentrate on performance of Holstein calves. International Journal of Dairy Science 2(1): 79-84 https://doi.org/10.3923/ijds.2007.79.84

Gorgulu M, Siuta A, Yurtseven S, Ongel E \& Kutlu H R (2003). Effect of probiotics on growing performance and health of calves. Cuban Journal of Agricultural Science 37(2): 125-129

Guler O, Yanar M, Bayram B \& Metin J (2006). Performance and health of dairy calves fed limited amounts of acidified milk replacer. South African Journal of Animal Science 36(3): 149-154

Higginbothem G E \& Bath L D (1993). Evaluation of Lactobacillus fermentation cultures in calf feeding systems. Journal of Dairy Science 76: 615-620 https://doi.org/10.3168/jds.s0022-0302(93)77382-8

Hossaini S M R, Bojarpour M, Mamouei M, Asadian A \& Fayazi J (2010). Effects of probiotics and antibiotic supplementation in daily milk intake of newborn calves on feed intake body weight gain, fecal scores and health condition. Journal of Animal and Veterinary Advances 9(5): 872-875 https://doi.org/10.3923/javaa.2010.872.875

Isık M, Ekimler F, Özen N, \& Firat M Z (2004). Effects of using probiotics on the growth performance and health of dairy calves (in Turkish). Turkish Journal of Veterinary and Animal Sciences 28(1): 63-69

Jatkauskas J \& Vrotniakiene V (2010). Effects of probiotic dietary supplementation on diarrhoea patterns, faecal microbiota and performance of early weaned calves. Veterinarni Medicina 55(10): 494-503 https://doi.org/10.17221/2939-vetmed

Jenny B F, Vandijk H J \& Collins J A (1991). Performance and fecal flora of calves fed a Bacillus subtilis concentrate. Journal of Dairy Science 74(6):1968-1973 https://doi.org/10.3168/jds.s0022-0302(80)83098-0

Kaygisiz A, Bakir G, Yilmaz I \& Vanli Y (2011). Estimation of Variance Components and Genetic Parameters for Direct and Maternal Effects on Birth Weight in Brown Swiss Cattle. Pakistan Veterinary Journal 31(1): 70-74

Kim M K, Lee H G, Park J A, Kang S K \& Choi Y J (2011). Effect of feeding direct fed microbial as an alternative to antibiotics for the prophylaxis of calf diarrhea in Holstein calves. Asian-Australasian Journal of Animal Sciences 24(5): 643-649 https://doi.org/10.5713/ajas.2011.10322

Kocyigit R, Aydin R, Yanar M, Guler O, Diler A, Tuzemen N, Avci, Ozyurek S, Hirik E \& Kabakc1 D (2015). Effect of doses of direct-fed microbials plus exogenous fibrolytic enzymes supplementation on growth, feed efficiency ratio and fecal consistency index of Brown Swiss and Holstein Friesian calves. Indian Journal of Animal Research 49(1): 63-69 https://doi.org/10.5958/0976-0555.2015.00014.x

Krueger N A, Adesogan A T, Staples C R, Krueger W K, Kim S C, Littell R C \& Sollenberger L E (2008). Effect of method of applying fibrolytic enzymes or ammonia to Bermuda grass hay on feed intake, digestion and growth of beef steers. Journal of Animal Science 86(4): 882-889 https://doi.org/10.2527/jas.2006-717

Larson L L, Owen F G, Albright J L, Applemen R D, Lamb R C \& Muller L D (1977). Guidelines toward more uniformity in measuring and reporting calf experimental data. Journal of Dairy Science 60(6): 989-991

Martin P \& Bateson P (1993). Measuring Behaviour. Cambridge: Cambridge University Press UK.

Miller D R, Granzin B C, Elliott R \& Norton B W (2008). Effects of an exogenous enzyme, Roxazyme G2 Liquid, on milk production in pasture fed dairy cows. Animal Feed Science Technology 145(1): 194-208 https://doi.org/10.1016/j.anifeedsci.2007.05.049

Nocek J E \& Kautz W P (2006). Direct-fed microbial supplementation on ruminal digestion, health, and performance of pre- and postpartum dairy cattle. Journal of Dairy Science 89(1): 260-266 https://doi.org/10.3168/jds.s0022-0302(06)72090-2

Panivivat R, Kegley E B, Pennington J A, Kellog D V \& Krumpelman S L (2004). Growth performance and health of dairy calves bedded with different types of materials. Journal of Dairy Science 87(11):3736-3745 https://doi.org/10.3168/jds.s0022-0302(04)73512-2 
Ran T, Gomaa W M S, Shena Y Z, Saleem A M, Yang W Z \& McAllister T A (2019). Use of naturally sourced feed additives (lactobacillus fermentation products and enzymes) in growing and finishing steers: Effects on performance, carcass characteristics and blood metabolites. Animal Feed Science and Technology 254: 114-190 https://doi.org/10.1016/j.anifeedsci.2019.05.013

Seo J K, Kim S W, Kim M H, Upadhaya S D, Kam D K \& Ha J K (2010). Direct-fed microbials for ruminant animals. Asian-Australasian Journal of Animal Sciences 23(12): 1657-1667

Soydan E \& Sahin A (2016). Estimates of genetic parameters for direct and maternal effects with six different models on birth weight of Brown Swiss calves. The Journal of Animal \& Plant Sciences 26(3): 577-582

Sujani S \& Seresinhe R T (2015). Exogenous Enzymes in Ruminant Nutrition: A Review. Asian Journal of Animal Sciences 9(3): 85-99 https://doi.org/10.3923/ajas.2015.85.99

SPSS (2004). SPSS for Windows Release 13.0. SPSS Inc., Chicago, IL., USA.

Thakur S S, Verma M P, Ali B, Shelke S K \& Tomar S K (2010). Effect of exogenous fibrolytic enzymes supplementation on growth and nutrient utilization in Murrah buffalo calves. Indian Journal of Animal Science 80: 1217-1219

Tilki M, Mustafa S \& Mehmet C (2008). Genetic Parameters for Direct and Maternal Effects and Estimation of Breeding Values for Birth Weight in Brown Swiss Cattle. Turkish Journal of Veterinary and Animal Science 32(4): 287-292

Timmerman H M, Mulder L, Everts H, van Espen, D C, van der Wal E, Klaassen G, Rouwers S M G, Hartemink R, Rombouts F M \& Beynen A C (2005). Health and growth of veal calves fed milk replacers with or without probiotics. Journal of Dairy Science 88(6): 2154-2165 https://doi.org/10.3168/jds.s0022-0302(05)72891-5

Tuzemen N \& Yanar M (2004). Calf Rearing Tecniques (in Turkish). Atatürk University, Faculty of Agriculture Publications Number: 232, Erzurum

Ulger I (2019). Effects of pre-weaning probiotic treatments on growth performance and biochemical blood parameters of Holstein calves. Indian Journal of Animal Research 53:644-647 https://doi.org/10.18805/ijar.b-816

Weiss W P, Wyatt D J \& Mc Kelvey T R (2008). Effect of feeding propionibacteria on milk production by early lactation dairy cows. Journal of Dairy Science 91(2): 646-652

Wisener L V, Sargeant J M, O’Connor A M, Faires M C \& Glass-Kaastra S K (2015). The use of direct-fed microbials to reduce shedding of Escherichia coli $\mathrm{O} 157$ in beef cattle: a systematic review and meta-analysis. Zoonoses Public Health 62(2): 75-89 https://doi.org/10.1111/zph.12112

Yanar M, Tüzemen N \& Yuksel S (1999). Replacement of whole milk by milk substitute in diet of Brown Swiss calves. Indian Journal of Animal Sciences 69(8): 637-640

(C) 2021 by the authors. Licensee Ankara University, Faculty of Agriculture, Ankara, Turkey.

This article is an open access article distributed under the terms and conditions of the Creative

Commons Attribution (CC BY) license (http://creativecommons.org/licenses/by/4.0/). 